\title{
NOTES AND DISCUSSION
}

\section{A note on pragmatic constraints on syntax ${ }^{1}$}

\author{
ANDREAS TROTZKE \\ Stanford University
}

(Received 6 December 2016)

This note comments on Szendrói's (2017) claim that some of the pragmatic constraints on syntactic operations proposed in Trotzke (2015a) are not supported by convincing empirical evidence. Szendrói objects to two empirical points made by Trotzke. I will deal with these points in turn: Section 1 focuses on the syntactic flexibility of idioms discussed by Szendrôi, and Section 2 replies to her comments in the domain of island effects.

\section{PRAGMATIC CONSTRAINTS ON IDIOM SYNTAX}

In the domain of idiom syntax, Fanselow \& Lenertová (2011) argue that structural constraints can explain reordering options of idioms. Consider the following examples (primary structural accent is marked by capitals; less strong structural accent is indicated by small caps):
(a) Er hat die FLInte ins
KORN geworfen. he has the gun into-the grain thrown
(b) Die FLInte hat er ins KORN geworfen. the gun has he into-the grain thrown into-the grain has he the gun thrown 'He has given up.'
(c) *Ins KORN hat er die Flinte geworfen.

Fanselow \& Lenertová claim that once the structural accent on Korn has been assigned, the ordering die Flinte < ins Korn has been created and cannot be changed in subsequent derivational steps. Szendröi (2017; henceforth KS) and Trotzke (2015a; henceforth AT) agree with this view, but AT argues that structural constraints are not the only factor restricting reordering patterns of idioms. Specifically, AT claims that in these structurally-driven approaches, 'extra-linguistic (non-conventional) pragmatic factors may overwrite constraints ... and play a more crucial role in accounting for idiom flexibility' (AT: 90) than

[1] I thank Tom Wasow for discussing the idiom cases with me, and I gratefully acknowledge financial support from the German Research Foundation (DFG grant TR 1228/2-1). 
previously assumed. Note that the marked word order in (1c) is not ungrammatical. It is merely unacceptable in the idiomatic reading; fronting ins Korn in the literal reading of the idiom ('to throw a gun into a pile of grain') is perfectly acceptable.

AT provides examples where the idiomatic reading is also available when structural ordering constraints like the one above are violated. One of these examples is discussed by $\mathrm{KS}$ :

(2) (a) Er hat zwei FLIEgen mit einer KLAppe geschlagen. he has two flies with one swat hit

(b) Zwei FLIEgen hat er mit einer KLAppe geschlagen. two flies has he with one swat hit

(c) Mit einer KLAppe hat er zwei Fliegen geschlagen. with one swat has he two flies hit

'He has killed two birds with one stone.'

In accordance with AT's claims, KS points out that violation of the ordering zwei Fliegen < mit einer Klappe in (2c) does not destroy the idiomatic reading. AT's explanation of this observation refers to pragmatic considerations. In a nutshell, he claims that (2) might fall into one category with other cases he discusses in this context, for example, die Hand reichen 'to help somebody' (lit.: 'to hand over a hand'). These idioms and (2) above share the feature that their literal readings denote quite 'bizarre' events (see also Trotzke 2015b for more cases and details on the pragmatics involved). AT argues that structural ordering constraints can be violated in these idiomatic cases because the competing literal reading is highly implausible (i.e. bizarre).

However, concerning the difference between (1) and (2), KS claims that 'it is not obvious that the literal meaning is actually more accessible or plausible' (KS: 226) in cases like (1). While I agree that 'accessibility' should be measured more accurately in future studies by experimental investigations, it is important to note that the literal reading of the idiom in (2) would correspond to an event where someone beats up two flies with one swat - an action that should be judged as bizarre across speakers. Under normal physical circumstances, it is not possible to beat up flies. It is only possible to kill flies by using a swat, and this is clearly expressed by German verbs like erschlagen, totschlagen 'to beat a fly to death' or treffen 'to hit a fly' - even a metonymic (i.e. non-literal) version of schlagen is an unusual (and, I suppose, highly infrequent) lexical choice in this context.

All in all, I assume that KS misunderstood this piece of data, and, given the other examples discussed by AT, I conclude that the general claim made by AT might be on the right track: structural constraints can be violated in cases where the literal reading of an idiom does not make much sense for pragmatic reasons. 


\section{PRAGMATIC CONSTRAINTS IN THE DOMAIN OF ISLAND EFFECTS}

KS also takes issue with AT's pragmatic account of island effects. Concerning the general assumptions that AT formulates in this context, KS states that AT's discussion 'provides no motivation for these assumptions, or any evidence why they might hold' (KS: 227). In the interest of space, I will confine my remarks to only one assumption that is mentioned by KS in this passage: 'constituents conveying new information allow extraction most easily'.

One of the many observations AT cites in support of this claim are German data provided by Müller (2010: 68), who shows that was-für split out of external subjects improves by scrambling the object across the subject:
(a) ??Was haben denn für Bücher den Fritz beeindruckt? what have PART for books the Fritz impressed
(b) Was haben den Fritz denn für Bücher beeindruckt? what have the Fritz PART for books impressed 'What kind of books impressed Fritz?'

AT notes that scrambling the object den Fritz in (3b) alters the information structure such that the subject Bücher becomes 'more focal' (see AT: 99). AT shows that this is in accordance with prominent pragmatic accounts of island effects (Erteschik-Shir 1973 et seq.).

Patterns like (3) at least constitute potential evidence for the general claim that 'constituents conveying new information allow extraction most easily'. KS does not mention any of these data (see AT: 92-102 for more examples). Since she does not discuss the general claim stated above, it is thus not clear why KS rejects it.

\section{REFERENCES}

Erteschik-Shir, Nomi. 1973. On the nature of island constraints. Ph.D. dissertation, MIT.

Fanselow, Gisbert \& Denisa Lenertová. 2011. Left peripheral focus: Mismatches between syntax and information structure. Natural Language \& Linguistic Theory 29, 169-209.

Müller, Gereon. 2010. On deriving the CED effects from the PIC. Linguistic Inquiry 41, 35-82.

Szendrôi, Kriszta. 2017. Review of Andreas Trotzke, Rethinking syntactocentrism: Architectural issues and case studies at the syntax-pragmatics interface. Journal of Linguistics 53.1 223-228. [Published online by Cambridge University Press, 3 October 2016; doi:10.1017/S0022226716000311.]

Trotzke, Andreas. 2015a. Rethinking syntactocentrism: Architectural issues and case studies at the syntax-pragmatics interface. Amsterdam: John Benjamins.

Trotzke, Andreas. 2015b. How bizarre! A non-syntactic constraint on idiom syntax. In Anatol Stefanowitsch (ed.), Yearbook of the German Cognitive Linguistics Association, vol. 3, 219-230. Berlin: Mouton de Gruyter. 